\title{
Badan Permusyawaratan Desa (BPD) Dalam Pengawasan APBDesa Di Kabupaten Bima
}

\author{
${ }^{1}$ Firmansyah, ${ }^{2}$ Muhamadong, ${ }^{3}$ Arif Budiman, ${ }^{4}$ Hendra, ${ }^{5}$ Firliah Rizkiani \\ ${ }^{12345}$ Jurusan Ilmu Administrasi Sekolah Tinggi Ilmu Sosial dan Ilmu Politik (STISIP) Mbojo Bima \\ Email : fsyah1356@gmail.com,muhamadong@stisipmbojobima.ac.id,mhan_imoet@yahoo.com, \\ hen.dra13@yahoo.co.id, firliarizkiani89@gmail.com
}

\begin{abstract}
Abstrak. Dalam pembangunan desa pemerintahan desa berkedudukan sebagai subsistem dari sistem penyelenggaraan pemerintahan di Indonesia, sehingga desa memiliki kewenangan, tugas dan kewajiban untuk mengatur dan mengurus kepentingan masyarakatnya sendiri. Dalam menyelengarakan kewenangan, tugas, dan kewajiban desa dalam penyelenggaraan pemerintahan maupun pembangunan maka dibutuhkan sumber pendapatan desa. Beberapa hal yang menyebabkan desa membutuhkan sumber pendapatan yaitu: 1). Desa memiliki Anggaran Pendapatan dan Belanja Desa (APBDes) yang kecil dan sumber pendapatannya sangat bergantung pada bantuan yang sangat kecil pula. 2). Kesenjahteraan masyarakat desa yang rendah sehingga sulit bagi desa mempunyai Pendapatan Asli Desa (PADes) yang tinggi. 3). Masalah itu diikuti dengan rendahnya dana operasional desa untuk menjalankan pelayanan publik. 4). Banyak program pembangunan masuk ke desa akan tetapi hanya dikelola oleh Dinas. Pengawasan Badan Permusyawaratan Desa (BPD) dalam Pengelolaan Anggaran Pendapatan dan Belanja Desa (APBDesa) dengan anggaran diatas maka pengawasan itu penting, dengan melalui pengawasan yang ketat maka segala program pembangunan yang sudah disepakati tidak akan keluar dari rel atau aturan main yang ada baik dalam Undang - undang (UU), Peraturan Pemerintah (PP), Kemendagri, Nomor 113 Tentang Pengelolaan ADD, Kemendesa, Peraturan Daerah (Perda), Peraturan Bupati (Perbub) maupun Peraturan Desa (Perdes) sebagai payung hukum pelaksanaan (APBDes) untuk itu perlu adanya pengawasan langsung oleh Badan Permsyawaratan Desa (BPD). Pengawasan Badan Permusyawaratan Desa (BPD) dalam pengelolaan Anggaran Pendapatan dan Belanja Desa (APBDesa) yaitu persiapan anggaran, perencanaan anggaran dan evaluasi anggaran serta penggunaan Anggaran Pendapatan dan Belanja Desa (APBDesa) yaitu 30\% untuk penyelenggaraan Pemerintahan Desa dan $70 \%$ untuk Pembangunan, pemberdayaan masyarakat dan pembinaan kemasyarakatan, semua ini tidak terlepas dari prinsip-prinsip dalam pelaksanaan anggaran APBDesa yaitu diterima oleh semua pihak, sehingga dalam pengelolaan anggaran didalamnya terdapat transparansi anggaran, yang dapat dipertanggung jawabkan secara berkelanjutan. Jadi secara keseluruhan pengawasan yang dilakukan Badan Permusyawaratan Desa (BPD) adalah bagian yang tidak terpisahkan dari pengelolaan APBDesa oleh Pemerintah Desa.
\end{abstract}

Kata kunci: $B P D$, Pengawasan, APBDesa

\section{PENDAHULUAN}

Dalam pembangunan desa pemerintahan desa berkedudukan sebagai subsistem dari sistem penyelenggaraan pemerintahan di Indonesia, sehingga desa memiliki kewenangan, tugas dan kewajiban untuk mengatur dan mengurus kepentingan masyarakatnya sendiri.

Pemerintah Desa dalam rangka menyelengarakan kewenangan, tugas, dan kewajiban desa dalam penyelenggaraan pemerintahan maupun pembangunan maka dibutuhkan sumber pendapatan desa. Beberapa hal yang menyebabkan desa membutuhkan sumber pendapatan yaitu :

1) Desa memiliki Anggaran Pendapatan dan Belanja Desa (APBDes) yang kecil dan sumber pendapatannya sangat bergantung pada bantuan yang sangat kecil pula.

2) Kesenjahteraan masyarakat desa yang rendah sehingga sulit bagi desa mempunyai Pendapatan Asli Desa (PADes) yang tinggi. 
3). Masalah itu diikuti dengan rendahnya dana operasional desa untuk menjalankan pelayanan publik.

4). Banyak program pembangunan masuk ke desa akan tetapi hanya dikelola oleh Dinas.

Pemerintah Desa atau disebut juga disingkat Pemdes adalah lembaga pemerintah yang bertugas mengelola wilayah tingkat desa. Lembaga ini diatur melalui $\begin{array}{lll}\text { Peraturan } & \text { Pemerintah No. } 72\end{array}$ Tahun 2005 Tentang pemerintahan desa yang diterbitkan untuk melaksanakan ketentuan pasal 216 ayat (1) Undang Undang Nomor 32 Tahun 2004 tentang pemerintahan daerah. Begitu juga dalam undang undang Nomor 6 tahun 2014 tentang desa, seperti tertuang dalam pandangan umum pasal 1 Ketentuan umum adalah Penyelenggara Pemerintahan Desa adalah kepala desa dan Badan Permusyawaratan Desa (BPD) dapat melaksanakan urusan pemerintahan didesa sesuai asal usul desa dan adat istiadat masyarakat setempat. Selain itu pemerinth desa bersama BPD melaksanakan dasar - dasar kebijakan pemerintahan Desa, melaksanakan Musyawarah Desa, perencanaan pembangunan Desa, melaksanakan pemberdayaan dan pembinaan kemasyarakatan desa. Didalam penyelenggaran pemerintahan desa Kepala desa mempunyai wewenang :

1. Memimpin penyelenggaraan pemerintahan berdasarkan kebijakan yang ditetapkan bersama Badan Perwakilan Desa (BPD).

2. Mengajukan rancangan peraturan desa.

3. Menetapkan peraturan desa yang telah mendapat persetujuan bersama BPD.

4. Menyusun dan mengajukan rancangan peraturan desa mengenai Anggaran Pendapatan dan Belanja Desa (APBDesa) untuk dibahas dan ditetapkan bersama BPD.

5. Membina kehidupan masyarakat desa.

6. Membina perekonomian desa.

7. Mengoordinasikan pembangunan desa secara partisipatif.

8. Mewakili desanya di dalam dan di luar pengadilan dan dapat menunjuk kuasa hukum untuk mewakili sesuai dengan peraturan perundang undangan.

9. Melaksanakan wewenang lain sesuai dengan peraturan perundang undangan.

Secara Umum anggaran Desa seluruh Indonesia diprioritaskan untuk mendukung keberhasilan dalam pencapaian Visi dan Misi yang telah ditetapkan. Anggaran desa seluruh Indonesia dipergunakan untuk mendukung kelancaran pelaksanaan kegiatan dalam bidang penyelenggaraan pemerintahan, Pembangunan, Pemberdayaan masyarakat dan pembinaan kemasyarakatan. Kebijakan umum anggaran Desa berpedoman pada prinsip prinsip penganggaran yaitu :

1. Partisipasi Masyarakat Yang mengandung makna bahwa pengambilan keputusan dalam proses penyusunan dan penetapan anggaran sedapat mungkin melibatkan partisipasi masyarakat sehingga masyarakat mengetahui akan hak dan kewajibannya dalam pelaksanaan anggaran.

2. Transparansi Anggaran Anggaran yang disusun harus dapat menyajikan informasi secara terbuka dan mudah diakses oleh masyarakat meliputi tujuan, sasaran, sumber pendanaan, jenis objek belanja, manfaat dan dampak yang akan diperoleh dari suatu kegiatan yang dianggarkan.

3. Disiplin Anggaran, dalam hal ini a. Pendapatan yang direncanakan merupakan perkiraan yang terukur secara rasional yang dapat dicapai untuk setiap sumber pendapatan; b. Belanja yang dianggarkan merupakan batas tertinggi pengeluaran.

4. Keadilan Anggaran; Pungutan desa yang dibebankan kepada masyarakat haruslah mempertimbangkan kemampuan masyarakat untuk membayar;

5. Efisiensi dan Efektifitas anggaran Dana yang tersedia harus dimanfaatkan sebaik mungkin untuk dapat menghasilkan peningkatan pelayanan dan kesejahteraan bagi masyarakat sehingga perencanaan anggaran harus diperhitungkan secara cermat. 


\section{Pengelolaan Pendapatan Asli Desa}

Sumber pendapatan Desa - desa di indonesia hampir - hampir mirip namun yang membedakannya adalah Pendapatan Asli Desa (PADesa), karena ada desa yang memiliki sumber PADesanya sangat banyak dan dikelola secara profesional oleh pemerintah desa dan BPD, juga ada desa desa yang minim PADesanya dan hanya mengandalkan pemberian dari pemerintah pusat melalui DDA, dan dari pemerintah daerah melalui ADD dan PRD, bagian anggara ini adalah lumrah yang didapat oleh semua desa seluruh Indonesia, dana perimbangan ( Dana Desa (DDA) Alokasi Dana Desa (ADD) Pembagian Retribusi Daerah (PRD), Pendapatan Asli Desa (PADesa) dan Bantuan pemerintah dan pendapatan lain yang sah dan tidak mengikat.

Pengelolaan anggaran Pendapatan Desa diarahkan pada upaya optimalisasi penerimaan desa dalam rangka mencukupi pembiayaan dalam penyelenggaraan pemerintahan desa, pembangunan Desa dan pelayanan kemasyarakatan. Oleh karena itu dalam rangka mencukupi pembiayaan desa strategi yang dilakukan oleh pemerintah desa yaitu :

1.Tertib pelaksanaan administrasi keuangan desa;

2.Optimalisasi sumber - sumber pendapatan desa;

3.Optimalisasi pendapatan desa melalui pemanfaatan dan pengembangan potensi desa.

Adapun potensi yang menjadi sumber pendapatan yang dimiliki Desa kalau dapat dikelola dengan baik oleh pemerintah desa dan BPD adalah meliputi:

1. Pengelolaan BUMDes

2. Pengelolaan Bendungan/Embun Desa/DAM Desa nanti jasa airnya ditarik retribusinya untuk PADesa.

3. Melestarikan Daerah Pariwisata Desa.

4. Pengelolaan Usaha Desa (persewaan terop, kursi dan tenda);

5. Pengelolaan Gedung Serba Guna (GSG)

6. Pengelolaan Tanah Kas desa;

7. Pengelolaan Pasar desa dan Kios desa;
8. Membangun Pangkas Rambut dan Salon Kecantikan desa

9. Membuka Apotek desa

10.Mengelola potensi air tawar dan laut untuk budidaya ikan, rumpuh laut, udang dan keramba ikan

11.Hasil Pungutan Desa;

12.Mengelola usaha bersama antar desa

13. Mengelola berbagai macam Home industry yang ada di desa dan dialkukan oleh masyarakat secara kontinyu.

14. Bagi Hasil Pajak dan Restribusi Daerah, dan masih banyak lagi potensi yang ada didesa yang dapat dikelola dengan baik sebagai sumber PADesa.

Arah Pengelolaan Anggaran Pendapat Dan Belanja Desa (APBDesa)

Diberikannya kewenangan yang luas kepada desa berupa otonomi desa, hal ini merupakan peluang sekaligus tantangan bagi desa dalam mengatur dan mengurus rumah tangga desa menurut prakarsa, kreatifitas serta aspirasi masyarakat. Penggunaan Anggaran pendapatan dan Belanja Desa (APBDesa) didasarkan pada prioritas program kegiatan yang telah direncanakan serta perlu adanya pengawasan yang optimal. Pengalokasian anggaran pendapatan dan belanja desa melalui pembangunan adalah dilaksanakan berdasarkan pada hasil Musyawarah Rencana Pembangunan Desa (Musrenbangdes), sehingga hasilnya mencerminkan aspirasi dan sesuai kebutuhan masyarakat.

\section{Target Dalam Pengelolaan Anggaran Pendapatan Dan Belanja Desa (APBDesa)}

Target dan realisasi pendapatan setiap tahun Pemerintah Desa harus selalu menargetkan Pendapatan Desa akan tetapi realisasi pencapaiannya masih rendah khususnya pendapatan desa yang berasal dari kontribusi dari Pendapatan Asli Desa, selama ini Kontribusi terbesar untuk Pendapatan Asli Desa masih mengandalkan bantuan dari pemerintah pusat dan pemerintah daerah.

Hal ini menunjukan bahwa ketergantungan pemerintah desa dari APBDesa yang bersumber dari DDA, ADD, PRD sangat tinggi dan ini masih dijumpai secara nasional, oleh karena itu untuk 
mengurangi sifat ketergantung pemerintah desa kepada pemerintah atasan harus mulai dikurangi dengan catatan pemerintah harus mengelola potensi atau sumber pedapatan asli desa secara baik sehingga dapat memberikan kontribusi posistif terhadap kemandirian dan kemajuan desa yang bersangkutan lalu bagaimana strategi pencapaian target anggaran oleh pemerintah dan BPD secara optimal, maka harus dikaji dan dianalisis secara bersama-sama apa potensi - potensi desa yang mendatangkan PADesa salah satu indikatornya adalah sebagaimana yang diuraiakan diatas.

\section{Kebijakan Umum Keuangan Desa}

Undang - undang Nomor 6 Tahun 2014 tentang Desa, disebutkan bahwa Desa menjadi titik sentral otonomi desa, desa mempunyai kewenangan yang didasarkan pada azas otonomi dalam wujud otonomi yang luas, nyata dan bertanggung jawab, serta azas tugas pembantuan yang merupakan penugasan dari pemerintah provinsi maupun pemerintah Kabupaten, melaksanakan sebagian urusan pemerintahan ini berarti Desa diberikan keleluasaan menjalankan pemerintahan dan pembangunannya secara bertanggung jawab dengan melihat kondisi dan potensi lokalnya. Sehubungan dengan hal di atas, penyusunan Anggaran Pendapatan dan Belanja Desa (APBDesa) menjadi tahapan yang sangat krusial dalam memulai roda pemerintahan dan pembangunan setiap tahunnya dalam mewujudkan pelayanan dan kesejahteraan kepada masyarakat dengan lebih baik melalui perencanaan, pelaksanaan, pengawasan, pengendalian dan evaluasi pembangunan.

\section{Peran Dan Fungsi Badan Permusyawaratan Desa (BPD)}

Badan Permusyawaratan Desa (BPD) dapat membuat Rancangan. Peraturan Desa yang secara bersama - sama Pemerintah Desa ditetapkan menjadi Peraturan Desa. Dalam hal ini, BPD sebagai lembaga pengawasan memiliki kewajiban untuk melakukan kontrol terhadap implementasi peraturan desa, anggaran pendapatan dan belanja desa (APBDes) serta jalannya pemerintahan desa.
Didalam UU No.6 Tahun 2014 menyebutkan bahwa Undang - Undang ini memberikan posisi yang kuat kepada Kepala Desa. Undang -Undang ini juga memperkenalkan sebuah lembaga baru yang disebut Musyawarah Desa yang merupakan sebuah forum permusyawaratan yang diikuti oleh Badan Permusyawaratan Desa (BPD), pemerintah desa dan unsur masyarakat desa untuk memusyawarahkan hal yang bersifat strategis dalam penyelenggaraan pemerintahan desa, artinya setiap desa harus menghidupkan sebuah forum politik dimana termasuk di dalamnya terdapat persoalan strategis yang harus dimusyawarahkan bersama.

Nurcholis. Hanif (2011) “ Dalam rangka melaksanakan kewenangan yang dimiliki untuk mengatur dan mengurus kepentingan masyarakatnya, dibentuklah Badan. Permusyawaratan Desa (BPD) sebagai lembaga legislasi dan wadah yang berfungsi untuk menampung dan menyalurkan aspirasi masyarakat. Lembaga ini pada hakikatnya adalah mitra kerja Pemerintah Desa yang memiliki kedudukan yang sejajar dalam menyelenggarakan urusan pemerintahan, pembangunan, pemberdayaan masyarakat dan pembinaan kemasyarakatan desa"

Selain peranannya sebagai lembaga pengawas dalam setiap tahapan program pembangunan desa, Badan Permusyawaratan Desa (BPD) juga diberi kewenangan yang luas oleh pemerintah atasan, untuk melakukan perencanaan segala jenis kegiatan pembangunan dengan melalui musyawarah desa didalam pelaksanaan musyawarah desa tersebut Badan Permusyawaratan Desa (BPD) bertindak sebagai pemimpin rapat musyawarah, sebagaimana amanat Peraturan Menteri Desa Pembangunan Daerah Tertinggal, dan Transmigrasi Republik Indonesia,

Pasal 5 ayat 1 dan 3 PERMENDESA No. 2 Tentang Tata cara pengambilan Keputusan dalam Musyawarah pembangunan desa (2014) mengatakan sebagai berikut : Musyawarah desa diselenggarakan oleh Badan Permusyawaratan Desa (BPD) yang difasilitasi oleh pemerintah desa, dalam 
melaksanakan musyawarah desa pembangunan perlu melibatkan tokoh adat, tokoh agama, tokoh masyarakat, tokoh wanita, tokoh pendidikan, Kelompok tani, kelompok nelayan, kelompok perajin, kelompok pemerhati dan perlindungan anak, serta kelompok rumah tangga Miskin.

PASAL. 6. PERMENDES (2014), mengatakan Badan Permusyawaratan Desa (BPD) memiliki peranan (tugas, fungsi) dalam kegiatan pembangunan sebagai berikut:

a. Pemetaan Aspirasi masyarakat dan kebutuhan masyarakat.

b. Membentuk panitian kegiatan

c. Membuat jadwal kegiatan

d. Menentukan tempat kegiatan

e. Menyiapkan sarana dan prasarana

f. Menyiapkan media pembahasan

g. Mengundang peserta, musyawarah Desa Mengolah hasil musyawarah Pemerintah Desa bersama unsur Badan Permusyawatan Desa (BPD) wajib menyusun dan menetapkan Anggaran Pendapatan dan Belanja Desa (APBDesa) sesuai kebutuhan didesa, adapun Fungsi fungsi Badan Permusyawaratan Desa yang paling pokok adalah antara lain :

1. Menetapkan dan Menyetujui Peraturan Desa Bersama kepala Desa.

2. Menetapkan APBDesa Bersama Kepala Desa.

3. Melakukan pengawasan terhadap pelaksanaan APBDesa oleh Pmerintah Desa.

Badan Permusyawatan Desa (BPD) yang terdiri dari pemuka - pemuka masyarakat yang ada di desa yang berfungsi untuk mengayomi, adat istiadat, membuat peraturan desa, menampung dan menyalurkan aspirasi masyarakat serta melakukan pengawasan terhadap penyelenggaraan Pemerintah Desa.

Menurut Rozaki (2005:182). Badan Permusyawaratan Desa (BPD) merupakan lembaga yang menjadi sarana artikulasi aspirasi dan partisipasi serta alat ukur yang efektif terhadap pengelolaan pemerintah. Menurut Saragi (2004:244)

Jurnal Ilmu Sosial dan Pendidikan
Badan Permusyawaratan Desa (BPD) adalah mitra Pemerintah Desa dan merupakan pengawas jalannya Pemerintah Desa. Badan Permusyawaratan Desa (BPD) adalah mitra Pemerintahan Desa yang mempunyai fungsi besar dalam Pemerintahan Desa yaitu mengayomi, adat-istiadat, membuat peraturan desa bersama Kepala Desa, menjadi wadah untuk menampung dan menyalurkan aspirasi yang ada dari masyarakat dan melakukan pengawasan terhadap penyelenggaraan Pemerintahan Desa sehingga Kepala Desa harus berhati-hati dalam penggelolaan desanya.

Peran dan fungsi Badan

Permusyawaratan Desa (BPD) dalam meningkatkan sumber pendapatan Asli Desa (PADesa) sangat strategis, Badan Permusyawaratan Desa (BPD) harus mampu membaca dan menggali sumber - sumber PA Desa untuk menopang kegiatan pemerintahan desa, sebab desa yang mandiri adalah desa yang memiliki sumber PA Desa yang tersedia dan dapat dikelola secara baik untuk peningkatan kesejahteraan masyarakat dan perangkat pemerintahan yang ada didesa. Kecenderungan desa selama ini tidak memiliki kearifan lokal dalam mengelola anggara desa dengan sebaik - baiknya untuk peningkatan sumber - sumber pendapatan asli desa.

Desa merasa bahwa anggaran desa yang bersumber dari APBN dan APBD akan selalu ada dan tetap diberikan oleh pemerintah pusat dan daerah, pandangan seperti ini yang sangat keliru dan harus diluruskan sebab sesungguhnya negara memberikan anggaran dana desa yang bersumber dari APBN hanyalah stimulan untuk merangsang desa agar mau mengelola sumber daya alam yang tersedia didesa menjadi sumber keuangan desa, dalam artian bahwa desa harus memanfaatkan anggaran dari pemerintah pusat dan daerah ini untuk membuka dan memiliki usaha yang dapat mendatangkan pendapatan desa yang besar guna membiayai kebutuhan desa dan masyarakatnya agar menjadi desa yang mandiri dengan menggunakan hasil pengelolaan aset yang 
telah dibangun melalui anggaran pusat dan daerah tersebut.

Peluang untuk menambah income desa melalui pengelolaan Anggaran Pemdapatan dan Belanja Desa (APBDesa) sangat terbuka lebar tergantung sungguh ada kemauan pemerintah desa dan Badan Permusyawaratan Desa (BPD) dalam merencanakan penggunaan anggaran tersebut kepada hal - hal yang dapat mengarah pada peningkatan PA Desa. Misalnya pemerintah desa dan Badan Permusyawaratan Desa (BPD) membentuk Badan Usaha Miliki Desa (BUMDes), membangun Gedung Serba Guna (GSG), Membangun Bengkel Desa, membangun Pangkas Rambut Desa, membangun Bendungan Desa yang airnya dikelola oleh Petugas Pengatur dan Pengendalian Air (P3A) yang digaji oleh pemerintah desa dan hasil daripada pengelolaan Air tersebut dapat kembali ke desa, membangun kolam ikan desa sebagai tempat budidaya, membentuk kelompok kelompok penggemukan Sapi dan Kerbau, mengelola pariwisata alam gunung secara berkelanjutan apabila ada tempat - tempat yang memungkinkan untuk dijadikan areal pariwisata mestinya harus diamanfaatkan sebaik - baiknya untuk penambahan income desa

Mengelola pinggir pantai sebagai pariwisata sekaligus sebagai tempat budidaya udang Vename dan Windu serta masih banyak potensi lain yang ada didesa untuk dapat dikelola sebagai sumber PA Desa.

Semua yang ada didesa tergantung pemerintah desa dan Badan Permusyawaratan Desa (BPD) bagaimana cara mengelolah semua itu dengan baik, tidak ada kegiatan yang sia - sia dan tidak ada yang tidak bisa mendatangkan keuntungan yang besar manakala pengelolaannya anggaran desa oleh Pemerintah Desa mengedepankan transparansi, akuntabilitas dan partisipatif. Semua itu harus diawali dengan perencanaan yang matang dan penuh perhitungan agar pengelolaan keuangan desa tidaklah percuma, tentu setiap kegiatan Planning (perencanaan) dan pengorganisian anggaran dan actuating

Jurnal Ilmu Sosial dan Pendidikan serta controling harus kembali kepada pihak pihak yang berwewenang didesa. Terutama Badan permusyawarata Desa (BPD).

Perlu dijaga dan dilestarikan semua hal yang dapat memberikan kontribusi positif kepada kemajuan bangsa oleh semua kalangan yang berkepentingan didalamnya. Pelaksanaan hak, wewenang dan kebebasan otonomi desa menuntut tanggungjawab untuk memelihara integritas, persatuan dan kesatuan bangsa dalam ikatan Negara Kesatuan Republik Indonesia dan tanggungjawab untuk mewujudkan kesejahteraan rakyat yang dilaksanakan dalam koridor peraturan perundang - undangan yang berlaku (Widjaja, 2003:166).

Dalam hal pengelolaan pembangunan, dimana Undang-Undang Nomor 6 Tahun 2014 tentang Desa, menegaskan penggunaan dua pendekatan yang disebut “" Desa Membangun " dan " Membangun Desa". Penggabungan pendekatan itu dimaksudkan agar pembangunan desa efektif dalam meningkatkan kesejahteraan masyarakat desa dan kualitas hidup manusia serta penanggulangan kemiskinan melalui penyediaan pemenuhan kebutuhan dasar, pembangunan sarana dan prasarana, pengembangan potensi ekonomi lokal, serta pemanfaatan sumber daya alam dan lingkungan secara berkelanjutan. Untuk itu, desa harus menyusun perencanaan pembangunan sesuai dengan kewenangannya dengan mengacu pada perencanaan pembangunan daerah kabupaten/kota.

Dokumen rencana pembangunan desa merupakan satu-satunya dokumen perencanaan pembangunan di desa dan sebagai dasar penyusunan Anggaran Pendapatan dan Belanja Desa (APBDesa). Perencanaan pembangunan desa diselenggarakan dengan mengikutsertakan masyarakat desa melalui musyawarah perencanaan pembangunan desa, yang menetapkan prioritas, program, kegiatan, dan kebutuhan pembangunan desa yang didanai 
oleh Anggaran Pendapatan dan Belanja Desa, swadaya masyarakat desa, dan/atau Anggaran Pendapatan dan Belanja Daerah Kabupaten/Kota. Pembangunan desa dilaksanakan dengan semangat gotong royong serta memanfaatkan kearifan lokal dan sumber daya alam desa. Sementara itu, pelaksanaan program sektor yang masuk ke desa di informasikan kepada pemerintah desa dan di integrasikan dengan rencana pembangunan desa.

Pengawasan terhadap pelaksanaan pemerintahan merupakan salah satu alasan terpenting mengapa Badan Permusyawaratan Desa (BPD) perlu dibentuk. Pengawasan oleh Badan Permusyawaratan Desa (BPD) terhadap pelaksanaan pemerintahan desa yang dipimpin Kepala Desa merupakan tugas Badan Permusyawaratan Desa (BPD). Upaya pengawasan dimaksudkan untuk mengurangi adanya penyelewengan atas kewenangan kewenangan dan serta pengelolaan keuangan desa dalam penyelenggaraan pemerintahan desa.

$$
\text { Pengawasan menurut Siagian }
$$
(2004:125) adalah " proses pengamatan dari seluruh kegiatan organisasi guna lebih menjamin bahwa semua kegiatan yang sedang dilakukan sesuai dengan rencana yang telah ditentukan. Pengawasan merupakan proses melihat, mengamati dan memeriksa baik secara langsung maupun tidak langsung mengenai semua kegiatan yang sedang dilaksanakan, apakah sudah sesuai dengan perencanaan yang sudah ditentukan sebelumnya".

Dengan adanya pengawasan maka perencanaan yang dibuat diharapkan dapat berjalan dan terlaksana dengan maksimal, karena tanpa adanya pengawasan dari pihak yang bersangkutan maka perencanaan yang telah ditetapkan akan sulit diterapkan sehingga tujuan yang diharapkan akan sulit terwujud. Badan Permusyawaratan Desa (BPD) sebagai perwujudan demokrasi ditingkat desa dibentuk, yang berperan sebagai mitra kerja Pemerintahan Desa dan pengawasan terhadap pelaksanaan
Pengelolaan Anggaran Pendapatan dan Belanja Desa (APBDesa)

Menurut Wasistiono dan Tahir (2006:17) “ Alokasi Dana Desa (ADD) adalah pembiayaan atau keuangan merupakan faktor esensial dalam mendukung penyelenggaraan otonomi yang sekarang telah diberikan kepada desa, maka untuk mengatur dan menggurus rumah tangganya sendiri, desa membutuhkan dana atau biaya yang memadai sebagai dukungan untuk melaksanakan kewenangan yang dimiliki. Alokasi Dana Desa (ADD) adalah anggaran atau dana yang diberikan kepada desa yang didasarkan pada Peraturan Daerah yang bertujuan untuk pembiayaan Pemerintahan Desa dalam pembangunan untuk memperkuat kemandirian desa"

Pengawasan Badan Permusyawaratan Desa (BPD) dalam Pengelolaan Anggaran Pendapatan dan Belanja Desa (APBDesa) dengan anggaran diatas maka pengawasan itu penting, dengan melalui pengawasan yang ketat maka segala program pembangunan yang sudah disepakati tidak akan keluar dari rel atau aturan main yang ada baik dalam Undang - undang (UU), Peraturan Pemerintah (PP), Kemendagri, Kemendesa, Peraturan Daerah (Perda), Peraturan Bupati (Perbub) maupun Peraturan Desa (Perdes) sebagai payung hukum pelaksanaan (APBDes) untuk itu perlu adanya pengawasan langsung oleh Badan Permsyawaratan Desa (BPD). Pengawasan Badan Permusyawaratan Desa (BPD) dalam pengelolaan Anggaran Pendapatan dan Belanja Desa (APBDesa) yaitu persiapan, perencanaan dan pelaksanaan serta penggunaan Anggaran Pendapatan dan Belanja Desa (APBDesa) yaitu 30\% untuk penyelenggaraan Pemerintahan Desa dan 70\% untuk pemberdayaan masyarakat, tidak terlepas dari prinsip-prinsip dalam pelaksanaan yaitu diterima semua pihak, transparansi, dapat dipertanggung jawabkan dan berkelanjutan. Jadi secara keseluruhan pengawasan yang dilakukan Badan Permusyawaratan Desa (BPD) baik pengelolaan dan penggunaan dilakukan secara langsung dan tidak langsung. Hal ini 
dilakukan untuk meningkatkan harkat dan martabat masyarakat desa melalui percepatan dan pemerataan pembangunan, melalui upaya pemberdayaan masyarakat sehingga tujuan pemberian Anggaran Pendapatan dan Belanja Desa (APBDesa) dapat tercapai sesuai harapan.

\section{METODE PENELITIAN}

Para ahli peneliti dalam kegiatan penelitian, dapat memilih berbagai jenis metode dalam melaksanakan penelitiannya. Menurut Halide dalam papayugan, M.M., dkk.(1992 : 11) mengatakan dengan mengunakan istilah metodelogi adalah “ berbagai langkah yang harus ditempuh secara sekuensi oleh seorang peneliti dalam menelaah problem yang sedang dipelajari untuk dipecahkan"

Penggunan metode penelitian bertujuan untuk memberikan peluang sebesar-besarnya bagi penemuan kebenaran yang obyektif, dan untuk menjaga agar pengetahuan dan pengembangannya memiliki nilai yang tinggi. Konsekwensi sebagai suatu karya ilmiah yang harus dipertanggungjawabkan obyektifitasnya, maka dalam jurnal ini penulis menggunakan rangkaian metode penelitian sebagai berikut:

\section{Jenis Penelitian}

Sugiyono (2003:4) membagi jenis penelitian atas tiga, yaitu Peneliitian Deskriptif, penelitian Komparatif, penelitian Asosiatif. Penelitian ini berbasis pada pendekatan deskriptif kualitatif. Dengan pendekatan ini diharapkan mampu menyajikan bentuk yang menyeluruh (holistik) dalam menganalisa fenomena tentang Fungsi Pengawasan APBDesa oleh Badan Permusyawaratan Desa (BPD).

Yatim Riyanto (2001 : 23) mengatakan bahwa "Penelitian deskriptif Kualitatif adalah penelitian yang diarahkan untuk mengetahui gejala-gejala, fakta-fakta, atau kejadiankejadian secara sistematis dan akurat " Fraenkel dan Wallen dalam Yatim Riyanto (2001:23) Penelitian Survei adalah merupakan penelitian dengan mengumpulkan informasi dari suatu sampel dengan menanyakan melalui angket atau interview supaya nantinya menggambarkan berbagai aspek.

Penelitian survei adalah penelitian yang bertujuan untuk : (1) mencari informasi faktual yang mendetail yang mencandra gejala yang ada. (2) mengidentifikasikan masalah-masalah atau untuk mendapatkan justifikasi keadaan dan kegiatan-kegiatan yang sedang berjalan. (3) untuk mengetahui hal-hal yang dilakukan oleh orang-orang yang menjadi sasaran penelitian dalam memecahkan masalah, sebagai bahan penyusunan rencana dan pengambilan keputusan dimasa yang akan datang.

\section{Tempat dan Waktu Penelitian}

Penelitian ini secara sengaja mengambil tempat atau lokasi pada beberapa Desa dan beberapa Kecamatan di Kabupaten Bima, dan atas pertimbangan - pertimbangan khusus peneliti, disamping persoalan kekurangan seperti keterbatasan Tenaga, dana, dan waktu peneliti, juga didasarkan pada alasan yang sangat mendasar yakni, karena peneliti juga adalah Pegawai Dinas Pemerintahan Desa Kabupaten Bima, serta peneliti kedua adalah Mantan Ketua BPD Desa Monta Baru Kecamatan Lambu Kabupaten Bima.

\section{Penentuan Informan Penelitian}

Penelitian kualitatif tidak mengenal adanya istilah populasi, tetapi oleh Spradley dalam Sugiyono (1998: 49) dinamakan social situation atau situasi sosial yang terdiri dari tiga hal yaitu tempat, pelaku, dan aktivitas yang berinteraksi secara sinergis. Sugiyono (2003:91) sampel dalam penelitian kualitatif bukan dinamakan responden melainkan informan kunci, narasumber, partisipan, teman atau guru dalam penelitian. Adapun informan dalam penelitian ini yakni :
1. Kepala DPMDesa
Kabupaten Bima
: 1 Orang
2. Camat
: 2 Orang
3. Kepala Desa
: 4 orang
4. Ketua, dan Anggota BPD :17 orang
5. Tokoh Masyarakat $\quad: 12$ orang

Jumlah :36 orang

Dan peneliti sendiri sebagai key informan penelitian 


\section{Jenis dan Sumber Data Penelitian Jenis Data}

Jenis data yang dipakai dalam penelitian ini yakni data kualitatif. Data yang dinyatakan dalam bentuk non angka/ non numeric atau biasa juga disebut atribut dalam istilah computer disebut data bertipe string. Pada pendekatan kualitatif, peneliti membuat suatu gambaran kompleks, meneliti kata-kata laporan terinci dari pandangan responden, dan melakukan studi pada situasi yang alami (Creswell, 2008 :15). Bogdan dan Taylor (Moleong, 1991:3) mengemukakan bahwa metodologi kualitatif merupakan prosedur penelitian yang menghasilkan data deskriptif berupa kata-kata tertulis maupun lisan dari orang-orang dan perilaku yang diamati. Penelitian kualitatif dilakukan pada kondisi alamiah dan bersifat penemuan.

Dalam penelitian kualitatif peneliti adalah instrumen kunci. Oleh karena itu peneliti harus memiliki bekal teori dan wawasan yang luas jadi bisa bertanya, menganalisis, dan mengkonstruksi obyek yang ditelitimenjadi lebih jelas. Penelitian ini lebih menekankan pada makna yang dan terikat nilai. Berdasarkan pada beberapa pendapat ahli diatas, maka data yang akan dipergunakan dalam penelitian ini adalah jenis data kualitatif.

\section{Sumber Data}

Data merupakan kumpulan fakta atau angka atau segala sesuatu yang dapat dipercaya kebenarannya sehinga dapat digunakan sebagai dasar penarikan kesimpulan. Data adalah sesuatu yang belum mempunyai arti bagi penerimanya dan masih memerlukan adanya sesuatu pengolahan.data bisa berwujud kepada gambar, suara, huruf, angka, matematika, bahasa ataupun simbolsimbol lainnya. Berdasarkan sumber data, terdapat 2 (dua) jenis data yaitu : Data Primer dan data sekunder :

1. Data primer menurut supranto (Ahmad Usman : 2008 : 232) yaitu data yang dikumpulkan sendiri oleh perorangan/suatu organisasi langsung memulai obyeknya. Atau dengan kata lain, data primer yaitu data yang langsung dikumpulkan oleh peneliti sendiri. Terdapat beberapa metode pengumpulan data primer, antara lain : Wawancara lansung dengan informan, sumber data atau responden; wawancara tak langsung (memulai informan-informan kunci ; dengan menggunakan angket (yang disebar atau melalui pos).

2. Data sekunder menurut supranto (Ahmad Usman, 2008: 232) yaitu data yang diperoleh dalam bentuk yang sudah jadi berupa publikasi data sudah dikumpulkan oleh pihak instansi lain. Atau dengan kata lain, data dipublikasi (data harga saham, komuditas dari surat kabar, majalah atau media elektronik) dan sumber data sekunder yang tak dipublikasi (arsip) pemerintah lembaga-lembaga penelitian dan sebagainya.

\section{Teknik Pengumpulan Data. Observasi}

Observasi merupakan metode pengumpul data yang menggunakan metode pengamatan terhadap obyek penelitian. Observasi dapat dilaksanakan secara langsung maupun tidak langsung. Observasi langsung adalah pengamatan secara langsung (tanpa alat) terhadap gejala-gejala obyek yang diselidiki, baik pengamatan itu dilakukan didalam situasi sebenarnya maupun dilakukan di dalam situasi buatan yang khusus diadakan. Sedangkan observasi tidak langsung adalah menandakan pengamatan terhadap gejalagejala subyek yang diselidiki dengan perantara sebuah alat pelaksanaannya dapat berlangsung didalam situasi yang sebenarnya maupun didalam situasi buatan. Yatim Riyanto (2001 : 96) kemudian Suharsimi Arikunto (2006 : 229) mengatakan bahwa " Dalam menggunakan metode observasi cara yang paling efektif adalah melengkapinya dengan format atau blangko pengamatan sebagai instrumen format yang disusun berisi item-item tentang kejadian atau tingkah laku yang digambarkan akan terjadi "

\section{Wawancara.}

Interview atau wawancara adalah merupakan metode pengumpulan data yang menghendaki komunikasi langsung antara penyelidik dengan subyek atau 
responden/informan. Dalam interview biasanya terjadi tanya jawab sepihak yang dilakukan secara sistematis dan berpijak pada tujuan penelitian. Yatim Riyanto (2001:83). Suharsimi Arikunto (2006 : 228) Wawancara harus dilaksanakan dengan efektif, artinya dalam kurun waktu yang sesingkat singkatnya dapat diperoleh dari sebanyak-banyaknya bahasa harus jelas, terarah. Suasana harus tetap rileks agar data yang diperoleh data yang obyektif dan dapat dipercaya.

\section{Dokumentasi}

Dokumentasi berasal dari kata dokumen, yang artinya barang-barang tertulis. Metode dokumentasi berarti cara mengumpulkan data dengan mencatat datadata yang sudah ada, metode ini lebih mudah dibandingkan dengan metode pengumpulan data yang lainnya (Yatim Riyanto, 2001: 103). Sementara Suharsimi Arikunto (2006: 231) mengatakan bahwa " Tidak kalah penting dari metode - metode lain, adalah metode dokumentasi, yaitu mencari data mengenai hal-hal atau variabel yang berupa catatan, transkrip, buku, surat kabar, majalah, prasasti, notulen rapat, lengger, agenda, dan sebagainya.

Dalam menggunakan metode dokumentasi ini, biasanya peneliti membuat instrument dokumentasi yang berisi instansi variable - variabel yang akan di dokumentasikan dengan menggunakan chek list untuk mencatat variabel yang sudah ditentukan tadi dan nantinya tinggal membubuhkan tanda chek list ditempat yang sesuai.

\section{Pengujian Keabsahan Data}

Keabsahan data merupakan persoalan yang cukup signifikan dalam penelitian kualitatif. Oleh arena itu, pemeriksaan keabsahan data dilakukan dengan triangular pengecekkan dengan teman sejawat, analisis terhadap kasus-kasus negatif penggunaan referensi yang akurat, pengecekan anggota dan keikutsertaan dilapangan dalam rentang waktu yang panjang.

Ada beberapa faktor yang mempengaruhi keabsahan penelitian kualitatif, yaitu : nilai subyektifitas, metode

Jurnal Ilmu Sosial dan Pendidikan pengumpulan data dan sumber data penelitian. Banyak hasil penelitian kualitatif diragukan kebenarannya karena beberapa hal, yaitu subyektifitas penelitian merupakan hal dominan dalam penelitian kualitatif, alat penelitian yang diandalkan

adalah wawancara dan observasi mengandung banyak kelemahan ketika dilakukan secara terbuka dan apalagi tanpa control, dan sumber data kualitatif kurang kredibel mempengaruhi hasil akurasi penelitian.

\section{Teknik Analisa Data}

Analisa data adalah merupakan usaha untuk menemukan jawaban atas pertanyaan yang diperoleh dari penelitian. Dalam penelitian ini teknik analisa data yang dipergunakan adalah model interaktif, dari miles dan huberman dalam Ahmad Usman (2008 : 71) yaitu dengan prosedur reduksi data; penyajian data; dan menarik kesimpulan data sebagai berikut :

a. Reduksi Data

Data yang diperoleh dari lokasi penelitian

(Kantor Desa dan Kantor BPD Di Kabupaten Bima) dituangkan dalam uraian atau laporan yang lengkap dan terperinci.

b. Penyajian Data

Penyajian data atau display data untuk memudahkan peneliti untuk melihat gambaran secara keseluruhan atau bagianbagian tertentu dari penelitian, oleh karena itu dalam penelitian ini ada penyajian tabel-tabel tentang penyelenggaraan alur koordinasi khusus dengan pihak-pihak terkait seperti Kepala Desa dan Badan Permusyawaratan Desa (BPD), serta koordinasi dengan tokoh masyarakat.

c. Menarik Kesimpulan

Verifikasi data dalam penelitian kualitatif dilakukan secara terus menerus sepanjang proses penelitian berlangsung, dengan bertambahnya data melalui proses verifikasi secaraterus menerus maka dapat memperoleh kesimpulan yang bersifat valid dan tepat.

\section{HASIL PENELITIAN PEMBAHASAN}

DAN 
Untuk mengetahui bagaimana peran Badan Permusyawaratan Desa (BPD) dalam Pengawasan Pelaksanaan APBDesa di Kabupaten Bima berikut Peneliti meakukan wawancara dengan informan yakni salah satu ketua BPD di Kecamatan Lambu, berikut petikan wawancaranya "Sebagai Ketua BPD apa dasar Hukum bapak melakukan pengawasan terhadap pelaksanaan APBDesa? dan berikut jawaban beliau :

"Dasar Hukum pengawasan Pengelolaan Anggaran Pendapatan dan Belanja Desa (APBDesa) oleh BPD Undang - undang Nomor 6 Tahun 2014 Tentang Desa, Peraturan Pemerintah (PP), Nomor 11 tahun 2019, Kemendagri Nomor 111 tentang Pengelolaan ADD, Kemendesa, Peraturan Daerah (Perda), Peraturan Bupati (Perbub) maupun Peraturan Desa (Perdes) sebagai payung hukum pelaksanaan (APBDes) untuk itu perlu adanya pengawasan langsung oleh Badan Permsyawaratan Desa (BPD)" (Wawancara, 23 September 2020)

Selanjutnya peneliti menanyakan kepada Kepala Dinas Pemberdayaan Masyarakat Desa (DPMDes) Kabupaten Bima tentang bagaimana tahapan pengawasan APBDesa yang dilakukan oleh BPD Di Kabupaten Bima dan berikut jawabannya :

"Pengawasan Pengelolaan Anggaran Pendapatan dan Belanja Desa oleh Badan Permusyawaratan Desa (BPD) yaitu meliputi: persiapan, perencanaan dan pelaksanaan serta penggunaan Anggaran Pendapatan dan Belanja Desa (APBDesa) yaitu $30 \%$ untuk penyelenggaraan Pemerintahan Desa dan $70 \%$, untuk pemberdayaan masyarakat, tidak terlepas dari prinsip-prinsip dalam pelaksanaan yaitu diterima semua pihak, transparansi, dapat dipertanggungjawabkan secara berkelanjutan. Jadi secara keseluruhan pengawasan yang dilakukan Badan Permusyawaratan Desa (BPD)" (Wawancara, 24 September 2020)

Untuk mengetahui pos anggaran yang bersumber dari mana saja yang dapat dilakukan pengawasan oleh Badan Permusyawaratan Desa (BPD) di Kabupaten

Jurnal Ilmu Sosial dan Pendidikan
Bima, berikut Peneliti melakukan wawancara langsung dengan Camat Kecamatan Sape Kabupaten Bima, sebagai Camat tentu Bapak mengetahui Sumber Anggaran dimana saja yang dapat diawasi oleh Badan Permusyawaratan Desa (BPD) Di Kabupaten Bima?

"Iya ... tentu kami mengetahui Pengawasan APBDesa tersebut yakni terdiri dari pos Dana Desa (DDA), Alokasi Dana Desa (ADD), Pos PRD, PADesa dan dari sumbersumber lain yang tidak mengikat ini semua merupakan proses pengamatan dari seluruh kegiatan pengelolaan APBDesa guna lebih menjamin bahwa semua kegiatan yang sedang dilakukan oleh Pemerintah Desa. Pengawasan Badan Permusyawaratan Desa (BPD) dalam pengawasan Badan Permusyawaratan Desa (BPD) apakah sudah sesuai dengan perencanaan pengelolaan dan penggunaan Alokasi Dana Desa (DDA), Alokasi Dana Desa (ADD), PRD dan PADesa yang merupakan serangkaian upaya untuk mengoptimalkan hasil dan rencana pembangunan yang tepat sasaran dan berkelanjutan di Desa" (Wawancara, 26 September 2020)

Dalam Pelaksanaan Pengawasan Pengelolaan Anggaran Pendapatan dan Belanja Desa (APBDesa) oleh Badan Permusyawaratan Desa (BPD), apakah tidak mengalami kesulitan dalam artian bahwa tidak ada sentimen dan ego sektoral oleh Kepala Desa sebagai pelaksana Anggaran Pendapatan dan Belanja Desa (APBDesa), untuk mengetahui hal tersebut berikut peneliti melakukan wawancara dengan salah satu ketua BPD di Kecamatan Sape Kabupaten Bima sebagai berikut: Dalam melaksanakan Fungsi Pengawasana dalam pengelolaan Anggaran Pendapatan dan Belanja Desa (APBDesa) apakah tidak ada sentimen atau ego sektoral yang ditunjukan oleh Kepala Desa terhadap Badan Permusyawaratan Desa (BPD) ? dan berikut jawaban Beliau :

"Masalah sentimen pribadi atau ego sektoral yang ditunjukan oleh Kepala Desa Kepada BPD sebenarnya tetap ada, namun kami BPD juga melaksanakan amanat Undang- 
Undang dan Peraturan yang mewajibkan kami untuk melakukan pengawasan terhadap Pengelolaan APBDesa, kami melaksanakan tugas dan fungsi kami dengan penuh rasa tanggungjawab yang tinggi, juga sebaliknya pemerintah desa juga menyadari akan hak dan kewajiban BPD yang dimuat didalam Peraturan perundang undangan yang berlaku sehingga mereka juga tidak begitu merasa di saingin" (Wawancara, 26 September 2020)

Ketika Badan Permusyawaratan desa melakukan pengawasan terhadap pengelolaan APBDesa, dari hasil wawancara diatas dapat ditemukan bahwa antara Kepala Desa dan BPD sering terjadi kesalahpahaman diantara keduanya, BPD wajib melaksanakan Pengawasana sesuai dengan fungsi dan tugas pokoknya, oleh karena itu bagi kepala desa seharusnya dapat memahami akan tugas dan fungsi BPD sebagai pengawas, pengawasan BPD tidak hanya bertumpu pada pelaksanaan APBdesa akan tetapi jauh lebih luas adalah mengawasi kinerja Kepala Desa.

Untuk mengetahui apakah dalam pengawasan terhadap pengelolaan anggaran APBDesa, Pemerintah Desa dan BPD melibatkan Masyarakat sebagai unsur pengawas dalam pengelolaan, Penyusunan, Penetapan dan Pelaksanaan APBDesa, berikut peneliti mewawancarai salah satu tokoh masyarakat di Kecamatan Wawo Kabupaten Bima : Apakah Badan Permusyawaratan Desa (BPD) melibatkan Tokoh-tokoh masyarakat dalam melakukan pengawasan Pengelolaan APBDesa ? dan berikut jawaban beliau :

"Iya .... Biasanya Pemerintah desa dan BPD sealalu melibatkan tokoh-tokoh masyarakat untuk berpartisipasi dalam pengawasan pengelolaan APBDesa, partisipasi masyarakat tersebut mengandung makna bahwa pengawasan dalam pengambilan keputusan terhadap proses Pengelolaan, penyusunan dan penetapan anggaran APBDesa dapat dilaksanakan dengan baik oleh BPD sedapat mungkin melibatkan partisipasi masyarakat sehingga

Jurnal Ilmu Sosial dan Pendidikan masyarakat mengetahui akan hak dan kewajibannya dalam pelaksanaan anggaran" (Wawancara, 27 September 2020)

Dalam pengelolaan APBDesa diharapkan bagi Pemerintah Desa dan BPD dapat mengedepankan asas transparansi demi menjamin rasa keadilan bagi setiap masyarakat yang akan dilayani, transparansi adalah kunci keberhasilan pemerintah desa dan BPD dalam menjalankan roda pemerintahan di desa, dengan transparansi ini pula maka tujuan pembangunan desa yang diharapkan masyarakat dapat tercapai dengan baik.

Untuk mengetahui hal itu peneliti melakukan wawancara dengan salah satu ketua BPD di Desa Maria Utara Kecamatan Wawo Kabupaten Bima : Apakah dalam pengawasan APBDesa tersebut ada rasa transparansi yang dilakukan oleh pemerintah terhadap pengelolaan APBDesa ? berikut jawaban informan :

"Iya...menurut saya selama bergulirnya Anggaran APBDesa ini saya melihat Pemerintah Desa cukup transparan dalam pengelolaan APBDesa, dan wajib hukumnya Pemerintah Desa harus Transparan terhadap pengelolaan Anggaran APBDesa, pada saat anggaran ini disusun pemerintah desa harus dapat menyajikan informasi secara terbuka dan mudah diakses oleh masyarakat meliputi tujuan, sasaran, sumber pendanaan, jenis objek belanja, manfaat dan dampak yang akan diperoleh dari suatu kegiatan yang dianggarkan" (Wawancara, 27 September 2020)

\section{KESIMPULAN}

1. Yang harus di lakukan oleh Pemerintah Desa dalam Pegelolaan APBDesa adalah meliputi: Persiapan anggaran, perencanaan anggaran dan Evaluasi anggaran serta penggunaan Anggaran Pendapatan dan Belanja Desa (APBDesa) sesuai kebutuhan masyarakat.

2. Adapun sumber-sumber anggaran yang diawasi oleh BPD adalah APBDesa 
tersebut yakni terdiri dari pos Dana Desa (DDA), Alokasi Dana Desa (ADD), Pos PRD, PADesa dan dari sumber-sumber lain yang tidak mengikat.

3. BPD dalam melakukan pengawasan APBDesa selalu melibatkan tokoh-tokoh masyarakat untuk berpartisipasi dalam pengawasan pengelolaan APBDesa.

4. Pemerintah Desa cukup transparan dalam pengelolaan APBDesa.

\section{DAFTAR PUSTAKA}

Ahmad Usman, 2008, Mari Belajar Meneliti, Genta press, Yogyakarta

Donelly, dkk (1999) Organisasi, Perilaku, Struktur, Airlangga Surabaya.

Fauzan, Ali (2010) dengan judul Implementasi Peraturan Pemerintah Nomor 72 Tahun 2005 Tentang Desa Terkait Dengan Peran Badan Permusyawaratan Desa Dalam Penyusunan dan Penetapan Peraturan Desa.

Fitrianingsih Langoy, 2016. Journal article Politico: Jurnal Ilmu Politik_Universitas Samratulangi

M.Manullang (2005) Asas-Asas Manajemen, Universitas Gadja Mada Press, Jogjakarta.

Moleong, Lexy J, 2007, Metodologi Penelitian Kualitatif, Cetakan Kesepuluh, Remaja Rosdakarya Bandung.

Muhamadong, 2018, Akuntabilitas Perangkat Dalam Pengelolaan Alokasi Dana Desa (Jurnal Administrasi Negara STISIP Mbojo Bima)

Poerwadarminta, W.J.S. 1976. Kamus umum Bahasa Indonesia. Balai Pustaka, Jakarta.

Riyanto Yatim, 2001, Metodologi Penelitian Pendidikan. SIC, Surabaya.

Soekanto, Soerjono. 2006. Sosiologi Suatu Pengantar. Jakarta: Raja Grafindo. Persada.

Soewarno Handayaningrat, 1991, Pengawasan dan Pengendalian Manajemen, Mandar Maju, Bandung.
Sugiyono, 2005, Metode Penelitian Administrasi Alfabeta Bandung.

Sutrisno, Hadi, 1984. statistik II, Yayasan penerbitan Fakultas psikologi UGM, Yogyakarta.

Wasistiono, dan Tahir, 2006 Makalah Tentang "Alokasi Dana Desa (ADD) adalah pembiayaan atau keuangan merupakan faktor esensial dalam mendukung penyelenggaraan otonomi Desa

Widjaja, 2013, Makalah Tentang “Otonomi Desa menuntut tanggungjawab untuk memelihara integritas, persatuan dan kesatuan bangsa dalam Ikatan Negara Kesatuan Republik Indonesia 